Pegem Journal of Education \& Instruction, 3(2), 2013, 01-12

Pegem Eğitim ve Öğretim Dergisi, 3(2), 2013, 01-12

www.pegegog.net

ZiHIN ENGELLiLER ÖĞRETMENLiĞi ÖĞRENCILERININ ÖĞRETMENLiK MESLEĞINE YÖNELIK TUTUMLARI ILE KAYGI DÜZEYLERI*

\title{
ATTITUDES TOWARDS PROFESSION AND ANXIETY LEVELS OF EDUCATION OF MENTALLY HANDICAPPED STUDENTS
}

\author{
Aydan AYDIN $^{\mathrm{a}^{* *}} ;$ Emrah TEKNECi $^{\mathrm{b}}$ \\ ${ }^{a}$ Marmara Üniversitesi Atatürk Eğitim Fakültesi, İstanbul/Türkiye \\ ${ }^{\mathrm{b}}$ Avrupa Rehabilitasyon Merkezi, İstanbul/ Türkiye
}

\section{Özet}

$\mathrm{Bu}$ araştırma ile zihin engelliler öğretmenliği öğrencilerinin öğretmenlik mesleğine yönelik tutumları ile kaygı düzeyleri arasındaki ilişkinin belirlenmesi amaçlanmıştır. Araştırmanın örneklemini, 2009- 2010 yılında Anadolu Üniversitesi (114 kişi), Gazi Üniversitesi (79 kişi), Marmara Üniversitesi (75 kişi), Ondokuz Mayıs Üniversitesi (73 kişi) ve Selçuk Üniversitesi (69 kişi) özel eğitim bölümü zihin engelliler öğretmenliğinde okumakta olan toplam 410 birinci ve dördüncü sınıf öğrencileri oluşturmaktadır. Araştırmada veri toplama aracı olarak, zihin engelliler öğretmen adaylarının mesleğe yönelik tutumlarını belirlemek amacıyla Çetin (2006) tarafından geliştirilen "Öğretmenlik Mesleği Tutum Ölçeği”, kaygı düzeylerini belirlemek amacıyla Spielberger (1979) tarafından geliştirilen "Durumluk-Süreklilik Kaygı Ölçeği" ve zihin engelliler öğretmen adayları hakkında bilgi toplamak amacıyla "Kişisel Bilgi Formu" kullanılmıştır. Araştırma sonucunda dördüncü sınıfta okuyan öğrencilerin öğretmenlik mesleğine yönelik tutum ölçeği puanları, birinci sınıfta okuyan öğrencilerin öğretmenlik mesleğine yönelik tutum ölçeği puanlarından daha yüksektir. Araştırmaya katılan zihinsel engelliler öğretmenliğinde okuyan öğrencilerin Durumluk ve Sürekli kaygı ölçeği puanları öğrencilerin sınıf düzeyine göre farklılaşmamaktadır. Ayrıca, zihin engelliler öğretmenliği adaylarının öğretmenlik mesleğine yönelik tutumlarının; cinsiyet ve alanda çalışıp çalışmama değişkenlerine göre farklılaşmaktadır. Durumluk ve sürekli kaygı düzeyleri ise; cinsiyet değişkenine göre farklılaşırken, alanda çalışıp çalışmama değişkenine göre farklılaşmamaktadır.

Anahtar kelimeler: Özel eğitim, tutum, kaygı.

\begin{abstract}
The purpose of this study is to determine the relationship between mental disability teaching students' attitudes toward teaching and their concern level. The sample of this study contains a total of 410 first and fourth grade students of special education department, mental disability teaching section in Anadolu university(114 students), Ondokuz mayıs university(73 students), Gazi unversity(79 students ) Marmara university(75 students ) and Selçuk university(69 students) at 2009-2010 academic year. In this study as a data collection tool "teaching profession attitude scale" developed by Çetin(2006) is used in purpose of determining mental disability teaching candidates' attitudes towards profession; "statecontinuity concern scale" developed by Spielberg(1979) is used to determine concern levels and "personel information form " is used in purpose of gathering information about teacher candidates. As a

\footnotetext{
* Bu çalışma 21. Ulusal Eğitim Bilimleri Kongresi - "21. Yüzyılda Okuryazarlık ve Geleceği, 12 - 14 Eylül 2012" sözlü bildiri olarak sunulmuştur.
}

** Yazar: aydanaydin@marmara.edu.tr
\end{abstract}


conclusion of the study, it is suggested that fourth grade students' scale scores of attitudes towards teaching profession is higher than that of first grade students. state continuity concern scale scores of Mental disability teaching students who has participated in this study is changeable according to grade levels. Also mental disability teacher candidates' attitudes towards this profession is differing by variants like gender and whether or not working at the field. State and continuity concern levels are changed by gender variant but not changed by whether or not working at the field variant.

Keywords: Special education, attitude, concern.

\section{Giriş}

Her birey ve toplum kendisini bulunduğu durumdan daha iyiye götürme isteği ile gelişim çabası gösterir. Bu çaba içersinde de değişim ve gelişimi destekleyecek bireyler, kurumlar ve meslekler önemli bir role sahiptir.

Hızlı gelişim ve değişimin yaşandığı günümüzde tüm ulusların en büyük çabası, bu değişim sürecine ayak uydurabilecek yeterlilikte donatılmış, nitelikli bireyler yetiştirmektir. Bu amacı gerçekleştirmede en etkili araç eğitimdir ve öğretmenler bu etkili aracın önemli bir öğesini oluşturur (Kuran, 2002). Öğretmenlik mesleğini yapan kişilerin kendilerinden beklenen sorumlulukları istenilen düzeyde yerine getirebilmeleri ve başarılı olabilmeleri, önemli ölçüde öğretmenlerin sahip oldukları niteliklere bağlıdır (Erdem ve Anılan, 2000). Öğretmen olacak kişilerinde nitelik ve yeterlilikleri kişisel özellikleri ile ilgili olduğu kadar öğretmen adaylarına sunulan eğitim programları ve eğitim ortamları ile de ilişkili olabilir.

Öğretmen adayları yeterliliklerin önemli bir kısmını lisans dönemlerinde edinirler. Bu dönemde öğretmen adayları alan bilgisinin yanında meslekle ilgili değer ve tutumlar kazanırlar (Lasek ve Wiesenbergova, 2007). Öğretim programlarının içeriklerinin yanı sıra, öğretmenin derse, öğretmenlik mesleğine, alana ve okula karşı farklı tutum ve davranışlarının öğretmen adayının başarısı, derse ilgisi, motivasyonu ve tutumunda etkili olacağı açıktır (ışık, S., Yaman, M., Soran, H., 2005). Başka bir deyişle öğretmenler sadece alanlarındaki bilgileri öğrenmiş kişiler olarak görülmemektedir (Azar, 2003). Bu nedenle, öğretmen adaylarının nitelikli bir hizmet öncesi eğitim programından geçirilmeleri meslekteki başarıları için gereklidir (Sözer, 1996).

Öğretmen adaylarına sunulacak nitelikli bir eğitim ortamı ve yaşantılarının; onlara mesleğin gereklerini yerine getirebilmeleri için yeterlilik kazandıracağı söylenebilir. Öğretmen adaylarına verilecek eğitim ile bilgi ve becerilerin kazandırılması temel hedeflerden biri olmakla beraber öğretmen adaylarının mesleğe bakış açıları, meslek ile ilgili duygu ve düşünceleri de şüphesiz önemli olacaktır. Başka bir deyişle; öğretmen adaylarının mesleğe yönelik tutumlarının, kendilerini aday oldukları öğretmenlik mesleğine hazırlamaları ve alanlarına yatırım yapmaları açısından etkili olacağı düşünülebilir. Kağıtçıbaşı (1988)' na göre de tutum; bir bireye ait ve bireye atfedilen bir eğilimdir. Arkonaç (2001) ise tutumun, genellikle bireye ait, doğrudan gözlenemese de, davranıştan önce gelen ve hareketlerimize rehberlik eden bir yapı olarak görülmekte olduğundan söz etmektedir.

Öğretmen adayları mesleklerine yönelik olumlu tutumlara sahip olarak yetiştirilebilirlerse, öğretmen olduklarında; görevlerini eksiksiz yerine getirirler, öğrencilere karşı daha olumlu davranışlar sergilerler, araştırmacı olurlar, yaratıcı düşünür ve yenilikleri öğrenme ortamına kolayca aktarırlar (Çeliköz ve Çetin, 2004).

Öğretmen adaylarının öğretmenlik mesleği ile ilgili tutumları, öğretmenlikle ilgili düşüncelerini yansıttığı gibi meslek yaşantıları üzerinde de etkili olabilmektedir (Çapri ve Çelikkaleli, 2008). Özellikle bir mesleğe yönelik olarak geliştirilen tutum, bireyin o meslekteki başarısının en önemli belirleyicisidir (Gürbüz ve Kışoğlu, 2007). Öğretmen adaylarının öğretmenlik mesleği ile ilgili olumlu düşüncelere sahip olmaları meslek yaşantılarını da olumlu yönde etkileyecektir (Johnson ve Howell, 2005; Oral, 2004; 
Senemoğlu ve Özçelik, 1989). Söz konusu alan özel eğitim alanı olunca; öğretmen adaylarının mesleğe yönelik tutumlarının mesleklerini yaparken, hem mesleki başarıları hem de mesleki doyumları açısından çok önemli bir etken olabileceği düşünülebilir. Çünkü özel eğitim alanın özellikle de zihin engelliler ile çalışacak olan öğretmen adayının verdiği eğitimin sonucunu görmesi için çok fazla emek, zaman ve enerji harcaması ve emeğinin karşılığı olarak da diğer alanlara göre daha küçük karşılıklarla yetinmesi söz konusudur. Ayrıca özel gereksinimli bireylerin ihtiyaçları ile ailelerinin beklentileri yanı sıra süreç içersinde yaşanabilecek; konusunda uzman yetişmiş personel yetersizliği, program ve işleyişlerdeki eksiklikler, özellikle de alanda karşılaşılan suistimaller zihin engelliler öğretmen adaylarının tutumları açısından son derece önem taşımaktadır.

Yapılan araştırmalar, öğretmenlerin tutum ve davranışlarının öğrenciler üzerinde çok önemli bir etkiye sahip olduğunu vurgulamaktadır (Çapa ve Çil, 2000; Güven, 2001; Temizkan, 2008). Mesleğe yönelik tutumun yanında öğretmen adaylarının yaşadığı kaygılar da meslek hayatlarını önemli oranda etkilemektedir. Cüceloğlu (1997) kaygının üzüntü, sıkıntı, korku, başarısızlık, sonucu bilememe ve yargılama duygularını içerdiğini, gelecekte ne olacağını bilememenin, insanlar için en önemli kaygı nedeni olduğunu ifade etmiştir. Mesleğe hazırlık aşamasında lisans eğitimini alan öğretmen adaylarının da özellikle gelecekle ilgili kaygılarının olacağı düşünülebilir.

Öğretmen adaylarının cinsiyeti, ailesinin sosyo-ekonomik düzeyi kişiliği ve duygusal durumuna ilişkin yapılan bazı araştırmalarda ana-baba mesleği, okuldaki başarı, barındığı yer, ailenin ekonomik durumu arkadaş çevresi öğrencide kaygı yaratıcı etmenler olarak görülmektedir (Çakmak ve Hevedanlı, 2004).

Öğretmenlik başlı başına emek gerektiren bir meslek iken öğretmenliğini zihin engelliler öğretmenliği alanında ifşa etmek ya da bunun eğitimini almayı sürdürmek verilecek emeği göze almaktır. Zihin engelliler öğretmenliği adayı olmak, alanda yaşanılan kaygının diğer öğretmenlik dallarından daha yüksek olması beklenebilir. Çünkü özel gereksinimli çocukların ve ailelerin ihtiyaçlarını karşılayabilmek, beklentilere cevap verebilmek, adayların sorumluluklarını artırırken, alana ve kendilerine yönelik sorumlulukları da artırmaktadır. Bu nedenlerden dolayı da, özel eğitim öğretmeni adaylarının mesleğe yönelik kaygılarının artacağı beklenebilir.

Zihin engelliler öğretmen adaylarının mesleğe yönelik tutum ve kaygılarının karşılaştırılarak, cinsiyet ve alanda çalışıp çalışmama değişkenlerine göre incelenmesi bu araştırmanın problem durumunu oluşturmaktadır.

\section{Amaç}

Yapılacak araştırmanın amacı, özel eğitim bölümü zihin engelliler öğretmenliğinde okumakta olan Birinci ve dördüncü sınıf öğrencilerinin mesleğe yönelik tutumları ile kaygı düzeylerinin karşılaştırılmasıdır. Ayrıca zihin engelliler öğretmenliğinde okumakta olan 1. ve 4. sınıf öğrencilerinin öğretmenlik mesleğine yönelik tutumları ile sürekli ve durumluk kaygı düzeylerinin cinsiyet ve alanda çalışıp çalışmama değişkenlerine göre farklılaşıp-farklılaşmadığına bakılmıştır.

\section{Araştırma Modeli}

\section{YÖNTEM}

$\mathrm{Bu}$ araştırma karşılaştırma türü ilişkisel tarama modelindedir. Karşılaştırma türü ilişkisel tarama modellerinde, en az iki değişken bulunup bunlardan birine göre gruplar oluşturularak diğer değişkene göre aralarında bir farklılaşma olup-olmadığı incelenir (Karasar, 1994).

\section{Örneklem}

Bu araştırmanın örneklemini; 2009-2010 öğretim yılında Anadolu Üniversitesi (114), Gazi Üniversitesi (79), Marmara Üniversitesi (75), On dokuz Mayıs Üniversitesi (73) ve Selçuk Üniversitesi (69) Özel Eğitim Bölümü Zihin Engelliler Öğretmenliği Anabilim Dalı birinci sınıf (221) ve dördüncü sınıf öğrencilerinden 
(189) toplam 410 öğretmen adayı oluşturmaktadır. Araştırmanın örneklem grubunu oluşturan öğrencilerin \% 36,3'ü erkek, \% 63,7'si bayan ve öğrencilerin \% 53,9'u 1.sınıf, \% 46,1'i 4.sınıfta okumaktadır. Örneklem grubunu oluşturan öğrencilerin veri toplama aracındaki deneyime sahip olmaolmama sorusuna verdikleri yanıta bakıldığında \% 50,2'sinin alan deneyimine sahip olduğu görülmüştür.

\section{Veri toplama araçları}

\section{Öğretmenlik Mesleği Tutum Ölçeği (ÖMTÖ)}

Öğretmen adaylarının öğretmenlik mesleğine yönelik tutumlarını belirlemek amacı ile Çetin (2006) tarafından geliştirilen ÖMTÖ kullanılmıştır. Sevgi, değer ve uyum olmak üzere üç boyuttan oluşan ölçek hem toplam puan hem de üç alt boyut için ayrı puan vermektedir. Cronbach Alfa güvenirlik katsayısı ölçeğin toplamı için .95, sevgi boyutu için .95, değer boyutu için .81, uyum boyutu için .76'dır. Ölçeğin geçerliği ise, Aşkar ve Erden (1968) tarafından geliştirilen ölçek kullanılarak test edilmiş ve elde edilen korelasyon katsayıları, toplam için $r=.85$, sevgi boyutu için $r=.97$, değer boyutu için $r=.57$ ve uyum boyutu için $r=.74$ olarak bulunmuştur. Beşli likert tipi olan ölçekte 15'i olumsuz 20'si olumlu 35 madde bulunmaktadır. Ölçek, olumlu cümleler "kuvvetle katılırım" seçeneğinden "asla katılmam" seçeneğine doğru “5, 4, 3, 2, 1" şeklinde puanlanırken, olumsuz cümleler de bunun tam tersi bir yol izlenerek "kuvvetle katılııı" seçeneğinden "asla katılmam" seçeneğine doğru "1, 2, 3, 4, 5" şeklinde puanlanmaktadır. Ölçekten alınabilecek en düşük puan 35, en yüksek puan 175 olup, 92-119 puan aralığının üstü olumlu, altı olumsuz, 92-119 aralığı ise nötr tutum olarak değerlendirilmektedir.

\section{Durumluk-Süreklilik Kaygı Ölçeği}

Spielberger (1979) tarafından geliştirilen ölçeğin geçerlilik ve güvenirliliği Öner ve LeCompte (1998) tarafından yapılmıştır. Durumluk-Sürekli Kaygı Envanteri toplam kırk maddeden oluşan iki ayrı ölçeği içerir. Durumluk Kaygı ölçeği, bireyin içinde bulunduğu duruma ilişkin duyguları dikkate alarak cevaplamasını gerektirir. Sürekli Kaygı ölçeği ise, bireyin genellikle nasıl hissettiğini betimlemesini gerektirir. Her iki ölçek yirmişer maddeden oluşmaktadır. Her iki ölçekten elde edilen toplam puan değeri 20 ile 80 arasında değişebilir. Puanın yüksek olması kaygı seviyesinin yüksek olduğuna işaret eder (Öner, 1998).

\section{Verilerin Toplanması ve Analizi}

Araştırma öncesinde üniversitelerin Özel Eğitim Bölümü başkanlıkları ile görüşülmüş ve yazılı izine gerek duyulmaksızın sözlü protokol ile 10 üniversiteye 820 anket posta ile ulaştırılmıştır. Bu anketlerden 610 tanesi tekrar posta ile gönderilmiştir. Elde edilen anketlerden 410 tanesi analize uygun bulunmuş ve değerlendirmeye alınmıştır.

\section{Verilerin Analizi}

Araştırma sonrasında elde edilen veriler SPSS 11.5 paket programına aktarılmış ve alt amaçlar doğrultusunda analizler yapılmıştır. Öğretmen adaylarının öğretmenlik mesleğine Yönelik Tutum puanları ile Durumluk ve sürekli Kaygı Ölçeği puanlarının ; sınıf düzeyine göre farklılaşp farklılaşmadığını belirlemek amacıyla ; Bağımsız grup t- Testi yapılmıştır.

Öğretmenlik Mesleğine Yönelik Tutum Ölçeği ile Durumluk ve Sürekli Kaygı Ölçeği puanlarının Puanlarının Cinsiyet ve Alanda Çalışıp Çalışmama Değişkenine Göre farklılaşıp farklılaşmadığını belirlemek amacıyla Bağımsız grup t- Testi yapılmıştır.

\section{BULGULAR}

$\mathrm{Bu}$ bölümde, araştırmada ele alınan amaçlar doğrultusunda toplanan verilerin istatistiksel çözümlemeleri sonucunda elde edilen bulgular ve yorumları yer almaktadır. 
Tablo 1.

Öğretmenlik Mesleğine Yönelik Tutum Ölçeği Puanlarının Sınıf Düzeyine Göre t- Testi Sonuçları

\begin{tabular}{lllllll}
\hline Gruplar & N & Ortalama & ss & sd & t & p \\
\hline Birinci Sınıf & 221 & 131,13 & 22,89 & & & \\
Dördüncü Sınıf & 189 & 143,26 & 19,98 & & $-5,667$ & 0,000 \\
\hline
\end{tabular}

Varyans Homojenliği liçin Levene Testi: $F=12,56 ; p=0.001$

Tablo1'de görüldüğü gibi birinci sınıfta okuyan öğrencilerin öğretmenlik mesleğine yönelik tutum ölçeği ortalaması 131,13, dördüncü sınıfta okuyan öğrencilerin öğretmenlik mesleğine yönelik tutum ölçeği ortalaması ise 143,26 'dır. Sınıf değişkenine ilişsin olarak yapılan bağımsız grup t-testi sonucuna göre "öğretmenlik mesleğine yönelik tutum ölçeği” puanları sınıf düzeyine göre farklılaşmaktadır. Bu sonuca göre dördüncü sınıfta okuyan öğrencilerin öğretmenlik mesleğine yönelik tutum ölçeği puanları, birinci sınıfta okuyan öğrencilerin öğretmenlik mesleğine yönelik tutum ölçeği puanlarından daha yüksektir (t=-5,667; $p<0.001)$.

Tablo 2.

Durumluk Kaygı Ölçeği Puanlarının Sınıf Düzeyine Göre t-Testi Sonuçları

\begin{tabular}{|c|c|c|c|c|c|c|}
\hline Gruplar & $\mathbf{N}$ & Ortalama & ss & sd & $t$ & p \\
\hline Birinci Sınıf & 221 & 41,76 & 6,99 & \multirow{2}{*}{408} & \multirow{2}{*}{,562 } & \multirow{2}{*}{,746 } \\
\hline Dördüncü Sınıf & 189 & 41,41 & 5,42 & & & \\
\hline
\end{tabular}

Tablo 2'de görüldüğü gibi birinci sınıfta okuyan öğrencilerin durumluk kaygı ölçeği ortalaması 41,76, dördüncü sınıfta okuyan öğrencilerin durumluk kaygı ölçeği ortalaması ise 41,41'dır. Sınıf değişkenine ilişkin olarak yapılan bağımsız grup t-testi sonucuna göre "durumluk kaygı ölçeği" puanları sınıf düzeyine göre farklılaşmamaktadır ( $t=.562 ; p>.05)$.

Tablo 3.

Sürekli Kaygı Ölçeği Puanlarının Sınıf Düzeyine Göre t- Testi Sonuçları

\begin{tabular}{lllllll}
\hline Gruplar & $\mathbf{N}$ & Ortalama & ss & sd & t & p \\
\hline Birinci Sınıf & 221 & 44,17 & 8,07 & & & \\
Dördüncü Sınıf & 189 & 42,66 & 8,73 & &,- 193 &, 847 \\
\hline \multicolumn{2}{l}{ Varyans Homojenliği Içcin Levene Testi: $F=, 906 ; p=, 342$} & & &
\end{tabular}

Varyans Homojenliği Için Levene Testi: F=,906; $p=, 342$

Tablo 3’de görüldüğü gibi birinci sınıfta okuyan öğrencilerin ortalaması 44,17, dördüncü sınıfta okuyan öğrencilerin ortalaması ise 42,66 'dır. Sınıf değişkenine ilişkin olarak yapılan bağımsız grup t-testi sonucuna göre "sürekli kaygı ölçeği" puanları sınıf düzeyine göre farklılaşmamaktadır (t=-.193; $p>.05)$.

Tablo 4.

Öğretmenlik Mesleğine Yönelik Tutum Ölçeği Puanlarının Cinsiyet Değişkenine Göre t- Testi Sonuçları

\begin{tabular}{|c|c|c|c|c|c|c|}
\hline Gruplar & $\mathbf{N}$ & Ortalama & SS & sd & $\mathbf{t}$ & $p$ \\
\hline Erkek & 149 & 125,59 & 21,05 & \multirow{2}{*}{408} & \multirow{2}{*}{$-8,195$} & \multirow{2}{*}{,000 } \\
\hline Bayan & 261 & 143,08 & 20,63 & & & \\
\hline
\end{tabular}

Varyans Homojenliği İçin Levene Testi: $F=, 010 ; p=, 922$ 
Tablo 4'de görüldüğü gibi erkek öğrencilerin öğretmenlik mesleğine yönelik tutum ölçeği ortalaması 125,59 , bayan öğrencilerin öğretmenlik mesleğine yönelik tutum ölçeği ortalaması ise 143,08'dir. Cinsiyet değişkenine ilişkin olarak yapılan bağımsız grup t-testi sonucuna göre "öğretmenlik mesleğine yönelik tutum ölçeği” puanları cinsiyete göre farklılaşmaktadır. Bu sonuca göre bayan öğrencilerin öğretmenlik mesleğine yönelik tutum ölçeği puanları, erkek öğrencilerin öğretmenlik mesleğine yönelik tutum ölçeği puanlarından daha yüksektir ( $t=-8,195 ; \mathrm{p}<0.000)$.

Tablo 5.

Öğretmenlik Mesleğine Yönelik Tutum Ölçeği Puanlarının Alanda Çalışıp Çalışmama Değişkenine Göre tTesti Sonuçları

\begin{tabular}{lllllll}
\hline Gruplar & $\mathbf{N}$ & Ortalama & ss & sd & $\mathbf{t}$ & $\mathbf{p}$ \\
\hline Evet & 206 & 144,19 & 20,10 & & & \\
Hayır & 204 & 129,18 & 22,12 & & & 708 \\
\hline
\end{tabular}

Varyans Homojenliği için Levene Testi: $F=5,73 ; p=, 017$

Tablo 5'de görüldüğü gibi alanda çalışan öğrencilerin öğretmenlik mesleğine yönelik tutum ölçeği ortalaması 144,19, alanda çalışmayan öğrencilerin öğretmenlik mesleğine yönelik tutum ölçeği ortalaması ise $129,18^{\prime}$ dir. Alanda çalışıp çalışmama değişkenine ilişkin olarak yapılan bağımsız grup ttesti sonucuna göre "öğretmenlik mesleğine yönelik tutum ölçeği" puanları alanda çalışıp çalışmama durumuna göre farklılaşmaktadır. Bu sonuca göre alanda çalışan öğrencilerin öğretmenlik mesleğine yönelik tutum ölçeği puanları, alanda çalışmayan öğrencilerin öğretmenlik mesleğine yönelik tutum ölçeği puanlarından daha yüksektir $(t=7,194 ; p<0.000)$.

Tablo 6.

Durumluk Kaygı Ölçeği Puanlarının Cinsiyet Değişkenine Göre t- Testi Sonuçları

\begin{tabular}{lllllll}
\hline Gruplar & $\mathbf{N}$ & Ortalama & ss & sd & $\mathbf{t}$ & $\mathbf{p}$ \\
\hline Erkek & 149 & 42,51 & 6,26 & & & \\
Bayan & 261 & 41,08 & 6,29 & 408 & 2,210 &, 028 \\
\hline
\end{tabular}

Varyans Homojenliği için Levene Testi: F=1,924; $p=, 156$

Tablo 6'da görüldüğü gibi erkek öğrencilerin durumluk kaygı ölçeği ortalaması 42,51, bayan öğrencilerin durumluk kaygı ölçeği ortalaması ise $41,08^{\prime}$ dir. Cinsiyet değişkenine ilişkin olarak yapılan bağımsız grup t-testi sonucuna göre "durumluk kaygı ölçeği” puanları cinsiyete göre farklılaşmaktadır. Bu sonuca göre erkek öğrencilerin durumluk kaygı ölçeği puanları, kız öğrencilerin durumluk kaygı ölçeği puanlarından daha yüksektir $(\mathrm{t}=2,210 ; \mathrm{p}<0.028)$.

Tablo 7

Durumluk Kaygı Ölçeği Puanlarının Alanda Çalışıp Çalışmama Değişkenine Göre t- Testi Sonuçları

\begin{tabular}{|c|c|c|c|c|c|c|}
\hline Gruplar & $\mathbf{N}$ & Ortalama & ss & sd & $\mathbf{t}$ & $\mathbf{p}$ \\
\hline Evet & 206 & 41,94 & 5,94 & \multirow[b]{2}{*}{408} & \multirow[b]{2}{*}{1,110} & \multirow[b]{2}{*}{--} \\
\hline Hayır & 204 & 41,25 & 6,65 & & & \\
\hline
\end{tabular}

Tablo 7'de görüldüğü gibi alanda çalışan öğrencilerin durumluk kaygı ölçeği ortalaması 41,94, alanda çalışmayan öğrencilerin durumluk kaygı ölçeği ortalaması ise 41,25 'dir. Alanda çalışıp çalışmama 
değişkenine ilişkin olarak yapılan bağımsız grup t-testi sonucuna göre "durumluk kaygı ölçeği" puanları alanda çalışıp çalışmama değişkenine göre farklılaşmamaktadır.

Tablo 8.

Sürekli Kaygı Ölçeği Puanlarının Cinsiyet Değişkenine Göre t- Testi Sonuçları

\begin{tabular}{lllllll}
\hline Gruplar & $\mathbf{N}$ & Ortalama & ss & sd & t & $\mathbf{p}$ \\
\hline Erkek & 149 & 42,40 & 8,11 & & & \\
Bayan & 261 & 44,08 & 8,53 & & $-1,950$ &, 050 \\
\hline \multicolumn{2}{l}{ Varyans Homojenliği için Levene Testi: $F=, 062 ; p=, 804$} & &
\end{tabular}

Varyans Homojenliği için Levene Testi: $F=, 062 ; p=, 804$

Tablo 8' de görüldüğü gibi erkek öğrencilerin sürekli kaygı ölçeği ortalaması 42,40, bayan öğrencilerin sürekli kaygı ölçeği ortalaması ise $44,08^{\prime}$ dir. Cinsiyet değişkenine ilişkin olarak yapılan bağımsız grup ttesti sonucuna göre "sürekli kaygı ölçeği" puanları cinsiyete göre farklılaşmaktadır. Bu sonuca göre bayan öğrencilerin sürekli kaygı ölçeği puanları, erkek öğrencilerin sürekli kaygı ölçeği puanlarından daha yüksektir ( $t=-1,950 ; p<0.050)$.

Tablo 9.

Sürekli Kaygı Ölçeği Puanlarının Alanda Çalışıp Çalışmama Değişkenine Göre t- Testi Sonuçları

\begin{tabular}{lllllll}
\hline Gruplar & $\mathbf{N}$ & Ortalama & ss & sd & $\mathbf{t}$ & $\mathbf{p}$ \\
\hline Evet & 206 & 43,39 & 8,93 & & & \\
Hayır & 204 & 43,55 & 7,87 & &,- 193 &, 847 \\
\hline
\end{tabular}

Varyans Homojenliği için Levene Testi: $F=1,981 ; p=, 160$

Tablo 9'da görüldüğü gibi alanda çalışan öğrencilerin sürekli kaygı ölçeği ortalaması 43,39, alanda çalışmayan öğrencilerin sürekli kaygı ölçeği ortalaması ise 43,55'dir. Alanda çalışıp çalışmama değişkenine ilişkin olarak yapılan bağımsı grup t-testi sonucuna göre "sürekli kaygı ölçeği" puanları alanda çalışıp çalışmama değişkenine göre farklılaşmamaktadır (t=-.193; p>.05).

\section{Sonuç ve Tartışma}

Araştırmaya katılan zihinsel engelliler öğretmenliğinde okuyan öğrencilerin öğretmenlik mesleğine yönelik tutum ölçeği puanları sınıf düzeyine göre farklılaşmaktadır. Araştırmamızın sonuçlarına göre dördüncü sınıfta okuyan öğrencilerin öğretmenlik mesleğine yönelik tutum ölçeği puanları, birinci sınıfta okuyan öğrencilerin öğretmenlik mesleğine yönelik tutum ölçeği puanlarından daha yüksektir ( $t=-5,667$; $\mathrm{p}<0.000)$. Bu sonuç öğretmen ve öğretmen adaylarıyla yapılmış çalışma sonuçları ile örtüşmektedir (Çeliköz ve Çetin, 2004; Tanel ve Diğerleri, 2007). Bu durum, öğretmen adaylarının üniversitede geçirdikleri yılların öğretmenliğe yönelik tutumları üzerinde olumlu etki sağladığı şeklinde yorumlanabilir. Yapılan bir diğer çalışmada ise (Güdek 2007) birinci sınıfta okuyan öğrencilerin öğretmenlik mesleğine yönelik tutum ölçeği puanları dördüncü sınıfta okuyan öğrencilerin puanlarından daha yüksek çıkmıştır. Ancak sınıf düzeyine göre tutum puanlarının değişiklik göstermediği çalışmalar da alanda mevcuttur ( Gerek, 2006; Aysu, 2007).

Araştırmaya katılan zihinsel engelliler öğretmenliğinde okuyan öğrencilerin durumluk kaygı ölçeği puanları sınıf düzeyine göre farklılaşmamaktadır. Bu durum durumluk kaygı düzeyinin sınıf düzeyine göre değişiklik göstermediği şeklinde yorumlanabilir. Ancak Çakmak ve Hevedanlı'nın (2005) çalışmasında birinci sınıf öğrencileri, ikinci ve üçüncü sınıf öğrencilerine göre daha kaygılı bulunmuştur. Bu durumu; birinci sınıflardaki kaygı seviyesinin yüksek olmasını yeni başlayan üniversite hayatı, değişen arkadaş çevresi, aileden ayrılma gibi sebeplerden kaynaklanıyor olabileceği şeklinde yorumlamışlardır. Aktekin ve 
diğerlerinin (1996) yapmış olduğu 5 yıl süren çalışmada öğrencilerin durumluk kaygı düzeyleri birinci ve ikinci yıllar arasında belirgin şekilde artmış, üçüncü yılda yüksek düzeyini korumuş ancak dördüncü ve beşinci sınıfta düşme göstermiştir.

Araştırmaya katılan zihinsel engelliler öğretmenliğinde okuyan öğrencilerin sürekli kaygı ölçeği puanları öğrencilerin sınıf düzeyine göre farklılaşmamaktadır. Bu sonuç öğretmen ve öğretmen adaylarıyla yapılmış çalışma sonuçları ile örtüşmemektedir (Aktekin ve diğerleri, 1996; Çakmak ve Hevedanlı, 2005; Genç, 2008). Bu farklı sonuçlar sürekli kaygı düzeyinin sınıf düzeyine göre değişken sonuçlar gösterebileceği şeklinde yorumlanabilir. Gülseven (2003) sürekli kaygıyı doğrudan doğruya çevreden gelen tehlikelere bağlı olmayan içsel kaynaklı bir kaygı olarak belirtmiştir ve sınıf düzeyine göre değişiklik göstermemesi beklenilen bu araştırmanın sonucu açısından beklenebilir bir durumdur.

Araştırmaya katılan zihinsel engelliler öğretmenliğinde okuyan öğrencilerin öğretmenlik mesleğine yönelik tutum ölçeği puanları cinsiyete göre farklılaşmaktadır. Araştırmanın sonuçlarına göre bayan öğrencilerin öğretmenlik mesleğine yönelik tutum ölçeği puanları, erkek öğrencilerin öğretmenlik mesleğine yönelik tutum ölçeği puanlarından daha yüksektir $(t=-8,195 ; p<0.000)$. Bu sonuçla örtüşen çalışmalar mevcuttur (Soran ve Diğerleri, 1996; Çeliköz ve Çetin, 2004; Kaya ve Büyükkasap, 2005; Güdek, 2007; Gerek, 2006; Ayarcı 2007; Pehlivan, 2008; Çetinkaya, 2007). Çapri ve Çelikkaleli (2008) bu sonucu; özellikle Türk toplumunun sosyal yapısı düşünüldüğünde, toplum tarafından kız çocuklarına daha çok öğretmenlik mesleğinin yakıştırılması ve bu doğrultuda telkinlerde bulunulması, kız öğretmen adaylarının öğretmenliğe ilişkin olumlu tutumlarının erkek öğretmen adaylarına göre daha yüksek olmasının bu bulgunun nedeni olarak değerlendirilebileceği şeklinde yorumlamıştır. Doğan ve Çoban (2009) ise bu durumu; toplumun öğretmenlik mesleğini, aile ve iş hayatını birlikte yürütebilecekleri kadına yönelik bir meslek olarak görmesi ve kızların da bu toplumsal değeri içselleştirmeleri şeklinde ifade etmiştir. Yamaner ve Kartal (2001) ise İnönü Üniversitesinde yaptıkları çalışmalarında erkek öğrencilerin tutum puanlarının kız öğrencilerden düşük çıkmasını toplumun erkeklerden beklentisinin, kadınlardan beklentisinden farklı olmasıyla açıklamışlardır. Toplumun bir erkeğin güvenilir, gelir sağlayan bir meslek sahibi olması beklemektedir. Toplumun bu bakış açısı erkek öğrencilerin öğretmenlik mesleğine yönelik tutumlarının kız öğrencilere oranla daha düşük çıkmasına etken olduğu şeklinde yorumlamışlardır. Bu sonuçlardan farklı olarak, öğretmenlik mesleğine yönelik tutumun cinsiyet değişkenine göre farklılık göstermediği çalışmalar da mevcuttur (Gürbüztürk, 2004; Karahan 2005; Sütçü, 1997; Tanel ve Diğerleri, 2007). Ayrıca yapılan bir diğer çalışmada ise (Duran 2009) erkek öğrencilerin öğretmenlik mesleğine yönelik tutum ölçeği puanları bayan öğrencilerin puanlarından daha yüksek çıkmıştır. Bu da, öğretmenlik mesleğine yönelik tutumun cinsiyet değişkenine göre uygulandığı gruplara göre değişkenlik gösterebildiği şeklinde yorumlanabilir.

Araştırmaya katılan zihinsel engelliler öğretmenliğinde okuyan öğrencilerin öğretmenlik mesleğine yönelik tutum ölçeği puanları alanda çalışıp çalışmama durumuna göre farklılaşmaktadır. Bu sonuca göre alanda çalışan öğrencilerin öğretmenlik mesleğine yönelik tutum ölçeği puanları, alanda çalışmayan öğrencilerin öğretmenlik mesleğine yönelik tutum ölçeği puanlarından daha yüksektir $(t=7,194$; $p<0.000$ ). Bu durum alanla ilgili dersleri aldıktan sonra alana ilişkin farkındalı̆ı̆ artması ardından gözlem ve staj yapmanın da mesleğe yönelik tutumu olumlu etkilediğini göstermektedir.

Araştırmaya katılan zihinsel engelliler öğretmenliğinde okuyan öğrencilerin durumluk kaygı ölçeği puanları cinsiyete göre farklılaşmaktadır. Bu sonuca göre erkek öğrencilerin durumluk kaygı ölçeği puanları, kız öğrencilerin durumluk kaygı ölçeği puanlarından daha yüksektir $(t=2,210 ; p<0.028)$. Bu sonuç öğretmen ve öğretmen adaylarıyla yapılmış çalışma sonuçları ile örtüşmemektedir (Canbaz ve Diğerleri, 2000; Varol, 1990; Taşğın, 2006) Yapılan bir diğer çalışmada ise (Akkaya, 1999) cinsiyet ile kaygı düzeyi arasında ilişki bulanamamıştır. Kız öğrencilerin kaygı düzeyi puanlarının erkek öğrencilerin kaygı düzeyi puanlarından yüksek çıktığı çalışmalar da alanda mevcuttur (Bozdam, 2008). Çakmak ve Hevedanlı (2004) bayan öğretmen adaylarının kaygı düzeylerinin yüksek bulunmasını; erkekler toplumun değerleri doğrultusunda daha "serbest" bir yaşantı sürdürürken, kızların ise baskı altına alındığı, 
bununda kızları rahatsız etmekte ve bazı haklarının ellerinden alındığını hissettikleri şeklinde yorumlamışlardır. Ayrıca araştırmaya katılan zihinsel engelliler öğretmenliğinde okuyan öğrencilerin durumluk kaygı ölçeği puanları alanda çalışıp çalışmama değişkenine göre farklılaşmamaktadır.

Araştırmaya katılan zihinsel engelliler öğretmenliğinde okuyan öğrencilerin sürekli kaygı ölçeği puanları öğrencilerin cinsiyetine göre farklılaşmaktadır. Bu sonuca göre bayan öğrencilerin sürekli kaygı ölçeği puanları, erkek öğrencilerin sürekli kaygı ölçeği puanlarından daha yüksektir $(t=-1,950 ; p<0.050)$. Bu sonuç öğretmen ve öğretmen adaylarıyla yapılmış çalışma sonuçları ile örtüşmektedir. (Canbaz ve diğerleri, 2001; Varol, 1990; Çakmak ve Hevedanlı, 2005; Akgün ve Diğerleri, 2007) Yapılan bazı çalışmalarda ise (Akkaya, 1999; Kocabaş, 2002; Genç, 2008; Develi, 2006;) cinsiyet ile kaygı düzeyi arasında ilişki bulunamamıştır. Ayrıca, araştırmaya katılan zihinsel engelliler öğretmenliğinde okuyan öğrencilerin sürekli kaygı ölçeği puanları öğrencilerin alanda çalışıp çalışmama değişkenine göre farklılaşmamaktadır. Bu sonuçlar durumluk ve sürekli kaygının daha çok kişiye özgü olduğunu, öğretmen adaylarının cinsiyetleri ve alandaki deneyimleri ile açıklanamayacağını düşündürebilir.

\section{Öneriler}

Bu araştırma Özel Eğitim Bölümü bulunan beş üniversitede gerçekleştirilmiş olup diğer üniversitelerin özel eğitim bölümleri ve diğer ana bilim dallarını da kapsayacak şekilde desenlenebilir. Ayrıca öğretmen adayları üzerinde etkili olan diğer faktörlerle (öz-yeterlilik, akademik benlik, kendini değerlendirme, yaratıcı düşünme, duygusal empati, vb.) karşılaştırmalı araştırmalar yapılması ve farklı değişkenlerinde incelenmesi önerilebilir.

\section{Kaynakça}

Akgün, A., Selahattin, G. ve Murat, A. (2007). İlköğretim fen ve matematik öğretmenliği öğrencilerinin kaygı düzeylerinin bazı değişkenlere göre incelenmesi. Elektronik Sosyal Bilimler Dergisi, 6(20), 283299.

Akkaya, S. (1999). Üniversite son sınıftaki öğrencilerin kaygılarını etkileyen etmenler. Yayınlanmamış yüksek lisans ezi, Ondokuz Mayıs Üniversitesi, Sosyal bilimler Enstitüsü, Samsun.

Aktekin, M., Yesim, Ş., Mehtap, T. ve Hakan, E. (1996). Tıp öğrencilerinde kaygı, depresyon ve bazı yaşam sorunlarının düzeyleri uzunlamasına bir çalışma. 8. Ulusal Halk Sağlığı Kongresi, Diyarbakır.

Arkonaç, S. (2001). Sosyal psikoloji. İstanbul: Alfa Basım Yayın Dağıtım Ltd.

Aysu, B. (2007). Okul öncesi öğretmen adaylarının öğretmenlik mesleğine karşı tutumlarının incelenmesi. Yayınlanmamış yüksek lisans tezi, Ankara Üniversitesi Fen Bilimleri Enstitüsü, Ankara.

Ayarcı, K. R. (2007). Sosyal bilgiler öğretmen adaylarının öğretmenlik mesleğine karşı ilgi, tutum ve beklenti düzeyleri. Yayınlanmamış yüksek lisans tezi, Celal Bayar Üniversitesi Sosyal Bilimler Enstitüsü, Manisa.

Azar, A. (2003). Öğretmenlik uygulaması ve okul deneyimi derslerine ilişkin görüşlerin yansımaları. Millî Eğitim Dergisi, 159, 181-194.

Bozdam, A. (2008). Öğretmen adaylarının mesleki kaygı düzeylerinin bazı değişkenler açısından incelenmesi. Yayınlanmamış yüksek lisans tezi, Selçuk Üniversitesi Sağlık Bilimleri Enstitüsü, Konya.

Canbaz, S., Tevfik, S. ve Yıldız, P. (2000). Samsun çıraklık eğitim merkezine devam eden çırakların durumluk-sürekli kaygı düzeylerinin değerlendirilmesi. Türk Tabipler Birliği Mesleki Sağlık ve Güvenlik Dergisi, Temmuz-Ağustos-Eylül, 16-22.

Cüceloğlu D., (1997). Insan ve davranışı. Remzi Kitapevi, İstanbul. 
Çakmak, Ö. ve Hevedanlı, M. (2004). Biyoloji öğretmen adaylarının kaygılarını etkileyen etmenler. 13. Ulusal Eğitim Bilimleri Kurultayı, Malatya.

Çakmak, Ö., Hevedanlı, M., (2005). Eğitim ve fen-edebiyat fakülteleri biyoloji bölümü öğrencilerinin kaygı düzeylerinin çeşitli değiş̧enler açııından incelenmesi. Elektronik Sosyal Bilimler Dergisi, 4 (14): 115127.

Çapa Y., ve Çil, N. (2000). Öğretmen adaylarının öğretmenlik mesleğine yönelik tutumlarının farklı değişkenler açısından incelenmesi. Hacettepe Üniversitesi Eğitim Fakültesi Dergisi, 18, 69-73.

Çapri, B. ve Çelikkaleli, Ö.(2008). Öğretmen adaylarının öğretmenliğe ilişkin tutum ve mesleki yeterlik inançlarının cinsiyet, program ve fakültelerine göre incelenmesi. İnönü Üniversitesi, Eğitim Fakültesi Dergisi, 9(15), 33-53.

Çeliköz, N. ve Çetin, F. (2004). Anadolu öğretmen lisesi öğrencilerinin öğretmenlik mesleğine yönelik tutumlarını etkileyen etmenler. Millî Eğitim Dergisi, 162.

Çetinkaya, R. (2007). Türkçe öğretmeni adaylarının yeterlilik algıları ve öğretmenlik mesleğine yönelik tutumları. Yayınlanmamış yüksek lisans tezi, Selçuk Üniversitesi Sosyal Bilimleri Enstitüsü, Konya.

Çetin, Ş. (2006). Öğretmenlik mesleği tutum ölçeğinin geliştirilmesi (Geçerlik ve güvenirlik çalışması). Gazi Üniversitesi Endüstriyel Sanatlar Eğitim Fakültesi Dergisi, 18, 28-37.

Develi, E. (2006). Konya'da ilköğretim okullarında görev yapan beden eğitimi öğretmenlerinin sürekli kaygı durumlarının incelenmesi. Yayınlanmamış yüksek lisans tezi, Selçuk Üniversitesi Sağlık Bilimleri Enstitüsü, Konya.

Dogan, T., ve Coban, A. E. (2009). Eğitim fakültesi öğrencilerinin öğretmenlik mesleğine yönelik tutumları ile kaygı düzeyleri arasındaki ilişkinin incelenmesi. Eğitim ve Bilim Dergisi, 34(153), 157-168.

Duran, O. (2009). Anadolu öğretmen liselerinde öğrenim gören son sınıf öğrencilerinin öğretmenlik mesleğine yönelik tutumları. Yayınlanmamış yüksek lisans tezi, Yeditepe Üniversitesi Sosyal Bilimler Enstitüsü, i̇stanbul.

Erdem, A. R., ve Anılan, H. (2000). PAÜ. Eğitim Fakültesi sınıf öğretmenliği öğrencilerinin öğretmenlik mesleğine ilişkin tutumları. Pamukkale Üniversitesi Eğitim Fakültesi Dergisi, 7, 144-149.

Genç, Handan (2008). Gazi Üniversitesi, Gazi Eğitim Fakültesi Güzel Sanatlar Eğitimi Bölümü Resim-iş eğitimi anabilim dalı öğrencilerinin kaygı düzeyleri üzerine bir durum çalışması. Yayınlanmamış yüksek lisans tezi, Gazi Üniversitesi Eğitim Bilimleri Enstitüsü, Ankara.

Gerek, R. (2006). Düziçi anadolu öğretmen lisesi öğrencilerinin öğretmenlik mesleğine yönelik tutumları. Yayınlanmamış yüksek lisans tezi, Kahramanmaraş Sütçü İmam Üniversitesi Sosyal Bilimler Enstitüsü, Kahramanmaraş.

Güdek, B. (2007). Eğitim fakültesi müzik eğitimi anabilim dalı 1. Ve 4. sınıf öğrencilerinin müzik öğretmenliği mesleğine yönelik tutumlarının öğrenciye ait farkı değişkenler açısından incelenmesi. Yayınlanmamış Doktora Tezi, Gazi Üniversitesi Eğitim Bilimleri Enstitüsü, Ankara.

Gülseven B., Şahin A.O., Sabuncu N. (2003). Subkutan (SC) enjeksiyon uygulamasına ilişkin psikomotor beceri eğitiminde öğrenim rehberi kullanımının başarı ve kaygı düzeyine etkisi. 2.Uluslararası9.Ulusal Hemşirelik Kongesi Kongre Kitabı, s.663, Antalya.

Gürbüz, H., ve Kışoğlu, M. (2007). Attitudes of the science and art faculty students and education faculty students attend the nonthesis graduated education program toward teaching profession. Erzincan Eğitim Fakültesi Dergisi, 9(2), 71-83. 
Gürbüztürk, O. ve Genç, S. Z. (2004). Öğretmen adaylarının öğretmenlik mesleğine ilişkin görüşleri. İnönü Üniversitesi Eğitim Fakültesi Dergisi, 5(7), 47-62.

Güven, i. (2001). Öğretmen yetiştirmenin uluslararası boyutu (UNESCO 45. Uluslararası Eğitim Kongresi). Millî Eğitim Dergisi, 150.

Işık, S., Yaman, M., Soran, H. (2005). Biyolojiye ve biyoloji öğretmenliğine karşı tutumlarına göre biyoloji öğretmen adaylarının tiplerinin belirlenmesi. Hacettepe Üniversitesi Eğitim Fakültesi Dergisi, 29: 110116.

Johnson, M. G., ve Howell, A. (2005). Change in pre-service teacher attitudes toward contemporary issues in education. 22 Temmuz 2010 tarihinde www.eric.ed.gov adresinden alınmıştır.

Kağıtçıbaşı, Ç. (1988) İnsan ve İnsanlar: Sosyal Psikolojiye Giriş, 5.Basım, İstanbul: Beta Yayınları, s.84-85.

Karahan, H. (2005). Ortaöğretim kurumlarında görev yapan coğrafya öğretmenlerinin diğer öğretmenlerle öğretmenlik tutumları açısından incelenmesi. Yayınlanmamış yüksek lisans tezi, Marmara Üniversitesi Eğitim Bilimleri Enstitüsü, İstanbul.

Karasar, N. (1994). Bilimsel Araştırma Yöntemi Ankara : 3 A Araştırma Danışmanlık Limited.

Kaya, A. ve E. Büyükkasap. (2005). Fizik öğretmenliği programı öğrencilerinin profilleri, öğretmenlik mesleğine yönelik tutum ve endişeleri: erzurum örneği. Kastamonu Eğitim Dergisi, 12(2), 367-380.

Kocabaş, A. (2002). Müzik Öğretiminde Bireysel Değerlendirmelerde Kaygı Düzeyi Üzerine Bir Çalışma, Marmara Üniversitesi Atatürk Eğitim Fakültesi, Eğitim Bilimleri Dergisi, 16, 119-130.

Kuran, K. (2002). Öğretmenlik Mesleği. Öğretmenlik Mesleğine Giriş (ed. Türkoğlu,A.). Mikro Yayıncılık. Ankara.

Lasek, J., ve Wiesenbergova, S. (2007). Prospective teachers'attitudes to their profession. The New Educational Review, 13(3-4), 129-136.

Oral, B. (2004) eğitim fakültesi öğrencilerinin öğretmenlik mesleğine ilişkin tutumları. Eğitim Araştırmaları, Ankara, Anı Yayıncılık 15, 88-98.

Öner N., Le Compte A. (1998). Süreksiz Durumluk/ Sürekli Kaygı Envanteri El Kitabı. Boğaziçi Üniversitesi Yayınları, İstanbul.

Pehlivan, K. B. (2008). Sınıf Öğretmeni Adaylarının Sosyo-Kültürel Özellikleri ve Öğretmenlik Mesleğine Yönelik Tutumları Üzerine Bir Çalışma, Mersin Üniversitesi Eğitim Fakültesi Dergisi, 4 (2). 151-168

Senemoğlu, N., ve Özçelik, D., A. (1989). Öğretmen adaylarına öğretmenlik bilgisi kazandırma bakımından fen-edebiyat ve eğitim fakültelerinin etkililiği. Çağdaş Eğitim Dergisi, 142, 18-21.

Soran, H., Demirci, C. ve Atav, E. (1996). Hacettepe Üniversitesi Eğitim Fakültesi Fen Bilimleri öğrencilerinin öğretmenlik mesleğine yönelik tutumlarının belirlenmesi. II. Ulusal Fen Bilimleri Eğitimi Sempozyumu, Marmara Üniversitesi Atatürk Eğitim Fakültesi, İstanbul.

Sözer, E. (1996). Üniversitelerde öğrenim gören öğretmen adaylarının öğretmenlik mesleğine yönelik tutumları. Anadolu Üniversitesi Eğitim Fakültesi Dergisi, 6(2), 7-21.

Sütçü, M. A. (1997). Din kültürü ve ahlak bilgisi öğretmenlerinin öğretmenlik tutumları. Yayınlanmamış yüksek lisans tezi. Gazi Üniversitesi Eğitim Bilimleri Enstitüsü, Ankara.

Tanel, R., Serap, K. Ş. ve Zafer, T. (2007). Fizik öğretmen adaylarının öğretmenlik mesleğine ilişkin tutumlarına farklı değişkenler açısından incelenmesi. Pamukkale Üniversitesi Eğitim Fakültesi Dergisi, $2(22), 1-9$ 
Taşğın, Ö., (2006). Beden eğitimi ve spor yüksekokulunda okuyan öğretmen adaylarının mesleki kaygı düzeylerinin bazı değişkenler açısından incelenmesi. Kastamonu Eğitim Dergisi, Ekim sayısı, 14 (2), 679-686.

Temizkan, M. (2008). Türkçe öğretmeni adaylarının öğretmenlik mesleğine yönelik tutumları üzerine bir araştırma. Türk Eğitim Bilimleri Dergisi, 6(3), 461-486.

Varol, Ş. (1990). Lise son sınıf öğrencilerinin kaygılarını etkileyen etmenler. Yayınlanmamış yüksek lisans tezi. Ondokuz Mayıs Üniversitesi Sosyal bilimler Enstitüsü, Samsun.

Yamaner, F., Kartal, A. (2001). İnönü üniversitesi eğitim fakültesi beden eğitimi ve spor bölümü öğrencilerinin, serbest zaman faaliyetlerinin değerlendirilmesi. Ankara Üniversitesi Beden Eğitimi ve Spor Bilimleri Dergisi, 1 (2-3-4), 133-140. 